\title{
Barns perspektiv på svensk vardagsrasism
}

\begin{abstract}
Children's perspectives on everyday racism in Sweden
Previous research has demonstrated that many children experience racism in the Swedish school system, a public institution that formally aims to combat all forms of discrimination. The question posed in this article is how racism can endure despite the school system's anti-racist agenda. Everyday racism is examined from children's perspectives, based upon eight focus groups with primary school pupils and a group of 11-year-old co-researchers who contributed to the interview planning and data analysis. The focus group discussions show that while everyday racism is typically concealed, invisible to teachers and other adults, racial microaggressions are nevertheless often detected by children themselves. The analysis reveals that children have the intention to speak up against everyday racism, but lack the necessary support and protection from adults. The article concludes that to fight racism in the Swedish school environment, adults must learn how everyday racism operates and in that learning process actively consult children for their perspectives.
\end{abstract}

Keywords: racism, discrimination, micro-aggression, youth, school

RASISM ÄR EN del av vardagen för många barn i Sverige. Rapporter från Barnombudsmannen, Friends och Rädda Barnen har nyligen pekat på att barn utsätts för rasism vid träningar och fritidsaktiviteter, på sociala medier och i onlinespel, men också under lektioner och raster i skolan (Abutaleb Rosenlundh, Lundström \& Vogel 2021; Barnombudsmannen 2021; Loodberg \& Abera 2021). Samtidigt fördöms rasism av samhällets institutioner; barn i Sverige har lagstadgad rätt att skyddas mot rasistisk diskriminering (SFS 2008:567; SFS 2010:800) och skolans verksamhet är tydligt inriktad på att förebygga och motverka rasism (Skolverket 2019). Trots dessa samhälleliga insatser fortsätter alltså rasism att prägla många barns vardag. Varför?

Den här artikeln tar sig an problemet genom att analysera vardagsrasism utifrån och med hjälp av barns perspektiv. Empiriskt bygger artikeln på en kvalitativ delstudie i Rädda Barnen-rapporten Vuxna - vad gör dom? (Abutaleb Rosenlundh, Lundström \& Vogel 2021). Undersökningen omfattade åtta fokusgrupper med elvaåringar som samtalade om rasism, där medforskande barn bidrog till intervjuguiden och analysen av det empiriska materialet. Studieresultaten analyseras i den här artikeln utifrån det teoretiska ramverket kring vardagsrasism. Syftet är att begripliggöra hur rasism verkar i miljöer där den aktivt fördöms. 


\section{Barns utsatthet för rasism}

Forskning under de senaste decennierna har visat att barn återkommande utsätts för rasism i Sverige. En översikt av forskningsläget mellan 1990 och 2016 visar att stigmatisering av elever med utländsk bakgrund kraftigt begränsar deras studieresultat (Behtoui, Hertzberg, Jonsson m.fl. 2019). Forskning visar också att rasistiskt utpekande av elever bidrar till otillräcklighetskänslor och förhöjda prestationskrav (Leon Rosales 2016; Wernesjö 2020) samt att barn redan i förskoleåldern tvingas förhålla sig till denna negativa särbehandling (Schwarz \& Lindqvist 2018). Samtidigt tenderar barn i utsatta storstadsförorter att stämplas som problematiska när de söker sig till högstatusskolor (Jonsson 2015, 2018; Pérez-Aronsson 2019), vilket enligt dem själva beror på mediers och politikers negativa beskrivning av deras bostadsområden (Dahlstedt 2017; Barnombudsmannen 2018:7; Dahlstedt 2018). Även på landsbygden utsätts barn för kränkningar och trakasserier på grund av sin hudfärg, sin kulturtillhörighet eller sina svenskkunskaper (Ljung Egeland 2015; Odenbring \& Johansson 2019). Ensamkommande ungdomar får särskilt svårt att etablera sig i det svenska samhället (Herz \& Lalander 2017); språkintroduktionsprogram för nyanlända fungerar i många fall som en parallell skolform vilken riskerar att förstärka deras utanförskap (Nilsson Folke 2017; Hagström 2018; Karlsson 2019).

Eftersom rasism antar en rad olika former utsätts barn på flera skilda sätt. I Sverige framträder rasism exempelvis som stereotypa föreställningar (Hjerm, Johansson Sevä \& Werner 2018; Miklikowska, Bohman \& Titzmann 2019; Ahmadi, Darvishpour, Ahmadi m.fl. 2020) och som antimuslimska uppfattningar och religiös diskriminering (Lindmark \& Sundström 2016; Gardell 2018; Nilsson 2019), men också som hot och våld från radikalnationalistiska organisationer, grupper och individer (Lundström \& Lundström 2016; Lööw 2017; Mattsson \& Johansson 2019). Rasism förekommer på strukturell nivå genom normer, rutiner och vardagshandlingar (Utredningen om makt, integration och strukturell diskriminering 2005; Utredningen om strukturell diskriminering på grund av etnisk eller religiös tillhörighet 2005; Khayati 2017), men också genom stigmatisering av bostadsområden med hög andel personer med utländsk bakgrund (Dahlstedt 2017; Behtoui, Hertzberg, Jonsson m.fl. 2019; Kadarik 2019).

I ett samhälle genomsyrat av rasism återfinns rasistiska tankefigurer och praktiker också hos barn. Det innebär att rasism iscensätts av barn själva när de interagerar med varandra. I mellan- och högstadiet utgör etnicitet den vanligaste grunden för trakasserier (Loodberg \& Abera 2021:22-31), och barn med utländsk bakgrund riskerar mobbning i högre grad än barn med båda föräldrarna födda i Sverige (Bjereld, Daneback \& Petzold 2015). Tilltagande exponering i sociala medier ökar dessutom risken för mobbning (Statens medieråd 2019), och kränkningar online inbegriper ofta rasistiska trakasserier (Furborg \& Cox 2016:20-21; Pérez Aronsson 2020; Sylwander 2020). Samtidigt kan rasistisk andrafiering ha ett välvilligt syfte, så till exempel vid "internationella" skolevenemang eller vid nyfikna men upprepade frågor om elevers migrationsbakgrund, trosuttryck eller språkkunskaper (Asplund, Thalberg \& Tovatt 2018; Pérez-Aronsson 2019). 
Barns allra första möte med rasism sker vanligtvis i grundskolan (Motsieloa 2003; Sixtensson 2018; Pérez-Aronsson 2019), trots att denna samhällsfunktion har ett tydligt uppdrag att skydda barn mot alla former av diskriminering (Arneback \& Jämte 2017; Edling 2018). Skolans agerande är grundläggande för samhällets arbete mot rasism (Miklikowska, Thijs \& Hjerm 2019; Bayram Özdemir \& Özdemir 2020), men likväl misslyckas skolpersonal med att identifiera och hantera rasistiska uttryck (Dovemark 2013; Katzin 2021). Därför väljer många barn att inte söka hjälp hos en vuxen när de utsätts för rasism i vardagen (Loodberg \& Warg 2019:21; Statens medieråd 2020:54; Abutaleb Rosenlundh, Lundström \& Vogel 2021).

Varför misslyckas då vuxenvärlden, trots höga ambitioner och resoluta handlingsplaner, med att se och motverka rasism? I den här artikeln utforskar jag den frågan utifrån det som inom kritisk rasismforskning benämns vardagsrasism, ett teoretiskt begrepp utformat för att studera de subtila uttryck för rasism som genomsyrar sociala interaktioner på både individuell och institutionell nivå (Essed 1991). Vardagsrasism inbegriper avsiktliga eller oavsiktliga uttryck för rangordnande särskiljning utifrån stereotypa föreställningar om ras, etnicitet, kultur, nationalitet eller religion. Vardagsrasism är något som aktiveras vid distinktionen mellan vi och dom, exempelvis mellan "svenskar" och "invandrare", genom en form av andrafiering som kan vara välvillig eller omedveten men som likväl fungerar rangordnande (Behtoui \& Jonsson 2013).

Vardagsrasism kan med andra ord förekomma trots antirasistiska ambitioner. Inom rasismforskningen används ibland begreppet "färgblindhet" för att beteckna hur en officiell antirasism förbiser de rasistiska särskiljningsmekanismernas historiska kontinuitet (Lentin 2011; Goldberg 2015; Pinder 2015) och hur dessa strukturerande faktorer skapat en vithetsnorm som upprätthåller särskiljning mellan grupper baserat på hudfärg (Lundström \& Hübinette 2020:20-23). Vithetsnormens färgblindhet osynliggör vardagsrasism och bidrar därigenom till att upprätthålla en "rasism utan rasister" (Bonilla-Silva 2017). Med hänvisning till vithetsnormativa idéer, som att invandrare behöver integreras i det svenska samhället, kan vardagsrasism verka i det fördolda och samtidigt vara högst kännbar för dem som blir utsatta (Odenbring \& Johansson 2019; Kristoffersson, Rönnqvist, Andersson m.fl. 2021).

Vardagsrasism handlar alltså inte primärt om uppfattningar eller attityder, utan om sociala praktiker och interaktioner som tillsammans bidrar till att upprätthålla en strukturell rasism (De los Reyes \& Wingborg 2002; Utredningen om makt, integration och strukturell diskriminering 2005; Mulinari \& Neergaard 2017). Vardagsrasismen uttrycks tydligast genom mikroaggressioner, avsiktliga eller oavsiktliga kränkningar som bygger på rasistiskt särskiljande (Sue 2010). Genom sitt tydliga utpekande utgör rasistiska mikroaggressioner, som vi snart ska se, en form av vardagsrasism som är lättare att identifiera än mer subtila uttryck för rangordnande särskiljning. Samspelet mellan mikroaggressioner och andrafiering, färgblindhet och vithetsnorm är centrala för den här artikelns analys av svensk vardagsrasism utifrån och med hjälp av barns perspektiv. 


\section{Barns perspektiv som studiedesign}

I den här artikeln analyserar jag vardagsrasism i den svenska skolan med hjälp av barns perspektiv. Denna studiedesign bygger på metodologin inom internationell barndomsforskning, där barns delaktighet och inflytande utgör en verksam del av kunskapsproduktionen (Christensen \& James 2017). Utgångspunkten är att barn inte enbart bör betraktas som omsorgsbehövande personer under utveckling, utan också som bärare av sociala erfarenheter och specifika kunskaper om att vara barn (Alderson 2008; Woodhead \& Faulkner 2008). Barns perspektiv har blivit en angelägenhet i forskning för, av och med barn. Det finns i dag en ökad förståelse av att barns erfarenheter, och därmed kunskaper, skiljer sig från vuxnas - utan att nödvändigtvis vara mindre kvalificerade (Solberg 1996; Christensen \& Prout 2002; Moosa-Mitha 2005). Med denna utgångspunkt betraktas barn som kunskapsbärare och experter på sin egen livssituation (Mayall 2000; Alderson \& Morrow 2004). Studiet av barns perspektiv vilar på en förståelse av barn som aktörer, som subjekt snarare än objekt (Alanen 2001; Woodhead \& Faulkner 2008; Bergnehr 2019). När skillnader mellan barn och vuxna bejakas - och barns perspektiv samtidigt beaktas - skapas nya förutsättningar för kunskapsproduktion.

Svensk barndomsforskning skiljer numera mellan termerna barnperspektiv och barns perspektiv (Halldén 2003, 2009; Johansson 2003). Att representera barn, exempelvis när deras rättigheter ska tillgodoses, är att ha ett barnperspektiv (Aronsson 2012). Att försöka se världen utifrån barns perspektiv handlar däremot om att aktivt ta del av "barns egna erfarenheter, uppfattningar och förståelse av sin livsvärld" (Sommer, Pramling Samuelsson \& Hundeide 2011:42). När vuxenvärlden lyssnar till barns perspektiv skapas större utrymme för minderårigas demokratiska inflytande (Clark, Kjørholt \& Moss 2005; Wall 2012). När barns perspektiv studeras produceras kunskap om unga människors handlingsutrymme och deras möjlighet att själva påverka olika situationer och sammanhang (Bergnehr 2018).

Forskning om barns perspektiv använder ofta metoder som engagerar barn i själva forskningsprocessen (Tisdall, Davis \& Gallagher 2009; Christensen \& James 2017; Nygren, Lindberg, Wärnestål m.fl. 2017). Barn kan medverka i forskningen i olika grad; som primärforskare formulerar de frågor och driver datainsamling och analys; som medforskare rekryteras de som sakkunniga för att stärka utvalda delar av forskningsprocessen (Spyrou 2011). När barn är medforskare involveras de i forskningsprocessens olika faser samtidigt som forskaren svarar för att medverkan sker på vuxnas initiativ och villkor (Clark, Kjørholt \& Moss 2005; Hernwall 2013). Medforskande barn bidrar med kunskaper om aktuell barndom, medan den vuxna forskaren initierar och ansvarar för studien (Woodhead \& Faulkner 2008); forskaren är lyhörd för barnens förslag, intar en vuxenposition som handledande medarbetare snarare än lärare och ansvarar samtidigt för medforskarnas trygghet och välbefinnande (Hillén 2013; Johansson 2013).

I den här studien har jag, som beskrivs i Rädda Barnen-rapporten (Abutaleb Rosenlundh, Lundström \& Vogel 2021:38-40), valt att involvera medforskande barn 
för att vinna kunskap om barns perspektiv på svensk vardagsrasism. Medforskarna rekryterades genom att jag kontaktade en skola belägen i en Stockholmsförort med låg socioekonomisk status och hög andel invånare med utländsk bakgrund. Polisen har betecknat förorten som ett särskilt utsatt område (Polismyndigheten 2021:7), vilket har bidragit till territoriell stigmatisering av den här och andra förorter där många boende har utländsk bakgrund (se Wacquant, Slater \& Pereira 2014).

Genom att rekrytera medforskare från ett särskilt utsatt område - särskilt utsatt för stigmatisering på basis av rasistiska föreställningar - hade jag möjlighet att ta del av de medforskande barnens perspektiv på rasism redan i studiens planeringsstadium. Tillsammans med min projektkollega Erica Mattelin konsulterade jag de elvaåriga medforskarna vid tre workshops under vårterminen 2021. Under den första träffen, som pågick i närmare tre timmar, medverkade fem barn. Här presenterade jag temat rasism genom att delge resultat från en enkätstudie med femteklassare runtom Sverige som genomfördes under 2020 och 2021. Enkätstudien utgjorde den första delstudien i ett Rädda Barnen-projekt gällande barns perspektiv på rasism, där min fokusgruppsstudie utgjorde den andra delstudien som kompletterande kvalitativt underlag. Eftersom enkätstudien genomfördes före fokusgruppstudien kunde jag integrera enkätsvaren i intervjusituationerna och därmed tolka resultaten tillsammans med intervjupersonerna och medforskarna.

Under vår första medforskarworkshop arbetade vi fram en intervjuguide, där barnen bidrog med viktiga synpunkter kring träffsäkerheten i intervjuguidens frågebatteri. Den tematiska intervjuguide jag sedan utformade hade öppna frågor kring erfarenheter av rasism och vuxnas agerande. Vid vår andra medforskarworkshop testades intervjuguiden, utifrån barnens egna önskemål om att själva få ingå i studien som intervjupersoner. Två barn hade nu valt att lämna uppdraget som medforskare. Kvar fanns tre flickor - Noor, Zara och Tahira - som engagerat diskuterade intervjuguidens teman (samtliga namn är pseudonymiserade). Efter fokusgruppsdiskussionen (Fg1) fick barnen skifta roll från intervjuperson till medforskare. De reflekterade över vilka frågor som fungerade bra och vilka som behövde revideras eller strykas, och bidrog därmed till ytterligare omarbetning av intervjuguiden, som nu bättre kunde fånga barns perspektiv på svensk vardagsrasism i skolan.

Efter intervjun med Noor, Zara och Tahira genomfördes ytterligare sju fokusgruppsträffar där jag bad om exempel på hur och i vilka situationer barn utsätts för rasism, med följdfrågor som handlade om vad vuxna gjort eller borde ha gjort i dessa situationer. I urvalsfasen kontaktades merparten av de skolor som ingått i Rädda Barnens enkätstudie, men endast några få rektorer erbjöd sina elever att delta i fokusgruppsstudien. Detta tillgänglighetsurval inbegrep tre skolor i Stockholmsregionen, en i Blekinge och en i Skåne. Skolorna låg i områden med stora variationer i fråga om invånare med utländsk bakgrund, vilket kan tjäna som indikator för olika grad av lagrade rasismerfarenheter.

Tre av skolorna (Fokusgrupp 2, Fg3, Fg4, Fg5, Fg6, Fg8) låg i områden där mindre än sex procent av befolkningen har utländsk bakgrund, enligt statistik inhämtad från Statistiska centralbyrån. Två av skolorna (Fg1, Fg7) låg däremot i områden där över 
20 procent av de boende har utländsk bakgrund. Varje fokusgrupp hade emellertid blandad sammansättning; ungefär en tredjedel av intervjupersonerna hade utländsk bakgrund, med båda föräldrarna födda utanför Sverige, och cirka en femtedel var pojkar. På de skolor som ingick i studien fick samtliga femteklassare och deras vårdnadshavare ta del av ett informationsbrev kring studiens syfte och genomförande, varpå eleverna anmälde intresse genom att underteckna en samtyckesblankett. Efter att vårdnadshavarna godkänt deltagandet komponerade läraren fokusgrupper för bästa möjliga gruppdynamik. Detta grindvaktsinflytande innebar emellertid en forskningsetisk fördel: lärarens elevkännedom bidrog till gruppsammansättningar med större trygghet för barnen. I det slutliga urvalet ingick 33 barn (varav tre medforskare). Samtliga gick i årskurs fem.

Vi var hänvisade till videomöten för att kunna genomföra medforskarworkshop och fokusgruppsintervjuer på olika platser i Sverige mitt under coronapandemin. Genom detta forum hade barnen möjlighet att använda chattfunktionen för att ställa privata frågor eller be om att få pausa eller avbryta studien. Den horisontella interaktionen mellan barnen stärktes också av att de satt på rad i samma rum och var gemensamt riktade mot samma skärm med webbkamera. Videosituationen motiverade dem dessutom att lyssna extra noga på varandra utan att avbryta. Eftersom obehagskänslor kunde skapas när barn delgav självupplevda trakasserier, skapade vi tillsammans med deltagarna i varje fokusgrupp tydliga regler för hur samtalet skulle stanna inom gruppen. Varje deltagare erbjöds möjlighet till uppföljande stödsamtal hos Rädda Barnens psykologteam. Genom en av fokusgrupperna framkom exempelvis starka indikationer på rasistisk mobbning. Vi bad därför skolans kurator, som i detta fall sammanställt fokusgruppen, att följa upp och med hjälp av skolledningen uppmärksamma och förebygga skolans problem med rasism. En annan förutsättning för barnens trygghet var konfidentialiteten. Jag lagrade därför inga personuppgifter i samband med studien. Endast ljudet spelades in och ljudfilerna raderades efter det att studien avslutats. Studiens design och genomförande har godkänts av Etikprövningsmyndigheten (Dnr 2020-06143).

De transkriberade intervjuerna analyserades sedan tematiskt med hjälp av mjukvaruprogrammet MAXQDA: jag kodade induktivt varje utsaga i transkriptionerna, som efter ytterligare genomläsningar kodades om eller slogs samman för att sedan insorteras under de övergripande kodkategorier som framträdde genom analysen (Bryant \& Charmaz 2012; Kuckartz \& Rädiker 2019). När intervjumaterialet var analyserat presenterade jag de preliminära resultaten vid en tredje medforskarworkshop. Noors, Zaras och Tahiras kritiska granskning bidrog till att både validera och modifiera mina analytiska slutsatser. Studiens vetenskapliga kvalitet stärktes också av värdefulla insikter från Petra Svedberg, René León Rosales och Fanny Pérez Aronsson, forskare som utifrån sin metodologiska och empiriska erfarenhet ingick i studiens sakkunniga referensgrupp. Som en kompletterande expertinstans till medforskarna konsulterades referensgruppen vid tre videomöten för diskussion av studiedesign, forskningsetik och analysresultat. 


\section{"Rasism i gympasalen"}

I följande resultatdel analyseras vardagsrasism i den svenska skolan utifrån de åtta fokusgruppsintervjuerna och med hjälp av de medforskande barnen. "Rasism i gympasalen" belyser tematiken och understryker artikelns huvudsakliga problemställning: förekomsten av rasism i en miljö där den officiellt motverkas. Den första underrubriken exemplifierar hur rasistiska tankefigurer kan återskapas bland barn och uttryckas genom mikroaggressioner: "Vi bor ju i Sverige och då borde utgångspunkten vara våra högtider." Den andra underrubriken visar hur barn själva, i det här fallet en av medforskarna, identifierar rasistisk andrafiering genom att understryka: "Det där var ju liksom lite rasistiskt." Det tredje intervjucitatet, "Jag vågade inte", belyser hur barn som bevittnar vardagsrasism inte får tillräckligt stöd och skydd för att kunna agera antirasistiskt. Den fjärde underrubriken kommer från det barn som självt blivit utsatt för rasism i gympasalen och som synliggör detta genom att betona: "Det händer på riktigt." Sammantaget tecknar resultatdelen en bild av hur barns erfarenheter och reflektioner kan bidra till förståelsen av vardagsrasismens verkningar i den svenska skolan.

\section{"Vi bor ju i Sverige och då borde utgångspunkten vara våra högtider"}

I Rädda Barnens enkätstudie, som genomfördes i samband med min fokusgruppstudie och som omfattade 1117 elever i årskurs fem vid 32 skolor runt om i Sverige, angav över hälften av barnen med utländsk bakgrund att de sett eller hört något rasistiskt på sin skola. Av dem som upplevt diskriminering hade de flesta blivit utsatta av andra barn, men några hade också blivit utsatta av skolpersonal och andra vuxna. Dessutom angav en femtedel av de barn som uppgav sig vara troende att skolan hindrat dem från trosuttryck som att be, att fasta eller att fira religiösa högtider (Abutaleb Rosenlundh, Lundström \& Vogel 2021:17).

Oscar: Får jag säga min åsikt om det här?

Markus: Ja, absolut.

I fokusgrupp åtta (Fg8) visar jag olika diagram från Rädda Barnens enkätstudie. När Oscar får veta att barn förhindras att be och fasta och att de inte får ledigt i samband med religiösa högtider, vill han lufta sin åsikt:

Oscar: Jag tycker absolut att man ska få följa sin religion fritt i Sverige. Men jag tycker inte att det ska gå ut över skolan. Fasta gör att du inte orkar med skolan, det kan påverka dina betyg och ditt karriärsval i framtiden. Man kanske vill be och så, men du missar skolan när du gör det, så jag tycker inte du ska få göra det i skolan, men du kan absolut göra det när du är hemma, på din fritid.

Markus: Tack så mycket för åsikten. Vad tänker ni andra om det?

Johan: Precis likadant.

Oscar: Är det någon som inte tycker så? 
Julia: Nej.

Ture: Jag tycker att man måste få göra det på sin fritid men i skolan tycker jag det är upp till skolan, eller läraren, om man ska få lov att göra det.

Isabella: Jag tänker ungefär som Ture, men också att man kan ju hitta stunder, typ på raster, då man kan få be och så. Högtider brukar ju oftast bara vara en dag, förutom vissa svenska högtider när alla skolor har lov. Då tycker jag att de kan få ledigt bara en dag. Och fasta, det är inte så svårt för de vuxna kan ju inte tvinga oss att äta. De får ju respektera om man fastar, för att man gör det ju i sin religion, eller kultur.

Lilly: Jag tycker också att högtiderna, vi firar ju de svenska högtiderna - det är då vi får lov - men det finns ganska många som kommer från andra länder och firar andra högtider. Men vi bor ju i Sverige och då tycker jag utgångspunkten borde vara våra högtider. Men kanske någon dag, kanske inte en hel vecka, men någon dag kan de fira den högtiden.

Julia: Jag tycker samma sak fast man kan ju fråga eleverna också. För vissa är det inte så viktigt att be, det är liksom ingenting man har gjort, och för vissa är det viktigt, de känner att man måste be. Då skulle man ju kunna fixa i schemat så om det är många som vill be så kan man ha en rast då. Och om det inte är någon som vill be så kan man ha det som vanligt.

Oscar: Det är som Isabella sa om fastan: absolut att du får fasta men du får liksom inte ..., du får ta konsekvenserna av det tycker jag. Det är liksom ditt val att fasta. Som Julia sa: om du ber då tycker jag inte att du ska påverka resten av klassen utan i så fall gör du så att det funkar med klassen också. Jag tycker inte att bara en eller ett fåtal personer ska påverka hela klassen så att de får det sämre.

Johan: $\mathrm{Om}$ de får ledigt vid sina speciella högtider då borde egentligen alla få ledigt på sin födelsedag. Men utgångspunkten i Sverige är de svenska högtiderna. Isabella: En grej på det Johan sa: jag tycker själv inte att man ska få ledigt på födelsedagar, för det är inte samma sak liksom. Det är inte som typ julafton, när man gör saker hela dagen och så. Folk fyller ju år varje dag, och det hade blivit lite bökigt om varje gång någon fyller år skulle de få ledigt.

Oscar: Det är ju det som är problemet med att folk tar ledigt när de har sina högtider!

Johan: Ja, det är exakt det jag försöker komma fram till! (Fg8)

Med högt känsloläge och virvlande åsiktsyttringar diskuterar fokusgruppsdeltagarna i vilken utsträckning de, alltså de barn "som kommer från andra länder och firar andra högtider", ska kunna uttrycka sin religion inom ramen för den svenska skolan. Tonen i samtalet är upprörd, barnen är irriterade på att de inte anpassar sig. Med den teoretiska förståelsen av vardagsrasism kan deras utsagor förstås i termer av mikroaggressioner.

Ture är resolut: han tycker att beslutet bör vara skolans eftersom de kan "göra det på sin fritid." Isabella har för sin del ett mjukare förhållningssätt till kulturell assimilering: skolan skulle kunna vara mer tillmötesgående så länge inte bön, fasta och högtidsfirande stör den gängse skolverksamheten. Hon menar att "de kan få ledigt 
bara en dag" och be "typ på raster". Här understryker Lilly den kulturella skillnaden mellan vi och dom genom att hänvisa till en normaliserad utgångspunkt: "vi bor ju i Sverige och då tycker jag utgångspunkten borde vara våra högtider." Julia ansluter sig till denna särskiljningsprincip men förespråkar liksom Isabella en mjukare assimilering med inkluderande lösningar, som schemaläggning där bönetider sammanfaller med raster. Oscar håller med Julia och Isabella men understryker att skolans anpassning också riskerar att gå för långt och därigenom drabba andra barn. Oscar tydliggör skiljelinjen genom att understryka att barn som fastar måste "ta konsekvenserna" eftersom det är deras "val". Johan spinner vidare på Oscars tanke med stigande irritation: Varför får de ledigt på "sina speciella högtider" när han inte får ledigt på sin födelsedag? Johans utsaga är emellertid retorisk, även han måste ju anpassa sig till "de svenska högtiderna" som faktiskt är "utgångspunkten i Sverige". Isabella prövar återigen en mjukare linje genom att påpeka orimligheten i Johans retoriska förslag om ledighet vid födelsedagar. Men hon utmanar inte de normaliserade idéer kring svenskhet som genomsyrar samtalet, särskiljningen och rangordningen mellan vi och dom. Det är denna särskiljande rangordning som Oscar och Johan hör Isabella bekräfta i hennes försök till problematisering; precis som födelsedagar inte berättigar ledighet skapas problem för "hela klassen" när "folk tar ledigt när de har sina högtider".

I den här fokusgruppen hade sju av de åtta deltagarna angett svensk bakgrund, med båda föräldrarna födda i Sverige. Utifrån en normativ position beskriver de i det här intervjusegmentet muslimer som en krävande grupp vars särskilda behov måste förhandlas med det svenska vi som intervjupersonerna själva identifierar sig med. Ibland uttrycks detta genom mikroaggressioner, som när möjligheten att följa icke-kristna traditioner uppfattas som orättvis (Odenbring \& Johansson 2019), och i dessa fall framträder vardagsrasismen så pass tydligt att den blir enklare att avslöja. Men även om åsikterna skiljer sig åt, tycks barnen här vara överens om att de andra skapar problem som på ett eller annat sätt behöver hanteras. Förslagen pendlar mellan mjukare och hårdare former av assimilering, men andrafieringen fungerar likväl som en särskiljande markering för svenskhet (Mattsson 2005). Detta förstärks av att barnen inte talar om sina egna erfarenheter, utan för resonemanget på ett generellt plan. Men när Oscar senare i intervjun för in samtalet på "rasism i gympasalen" tycks barnen emellertid, som vi snart ska se, få syn på rasismen i sin egen vardag. De omprövar sina tidigare förhållningsätt, de börjar lyssna i stället för att tala. Det är i detta skede som Mohamed, det enda av barnen i fokusgruppen som angett utländsk bakgrund, bryter tystnaden för att sätta ord på vardagsrasismen och därmed förändra positioneringarna inom fokusgruppen.

\section{"Det där var liksom lite rasistiskt"}

Efter att ha transkriberat fokusgrupp åtta konsulterade jag medforskarna Noor, Zara och Tahira för att ta del av deras perspektiv på samtalet. Vid vår tredje medforskarworkshop läste de utvalda segment från fokusgruppsintervjun och fick sedan frågan vad samtalet handlade om. Zara reagerade direkt på Oscars första utsaga om att barn borde vara fria att följa sin religion hemma men inte i skolan: 
Det där var liksom lite rasistiskt. Det är ju fritt här i Sverige att välja vilken religion man ska ha. Men det är ju inte helt fritt eftersom det inte är ditt val om du ska fira en högtid. Du kan liksom inte bara komma och säga till.

Zara, som själv har utländsk bakgrund, påpekar att Oscars frihetsbegrepp är förbundet med villkor och menar att religionsfriheten måste omfatta alla de barn som behöver ledighet vid icke-kristna högtider. Zara anser därför att det andrafierande uttalandet är rasistiskt. Samtidigt använder hon förbehållet lite, vilket indikerar att det handlar om en dold eller oartikulerad rasism. I andra fokusgrupper används på samma sätt trevande beteckningar som "lite rasistiskt" (Alexandra, Fg6) eller "en liten form av rasism" (Oscar, Fg8), vilket tyder på att begreppet förbehålls sällsynta företeelser. Olivia (Fg4) beskriver svårigheten med att identifiera vardagsrasism: ”Många vet liksom inte riktigt om det de blivit utsatta för var rasism, eller bara någonting som någon sa - det kan vara svårt att avgöra." Det medforskaren Zara ser är vardagsrasism uttryckt genom idén att religiöst berättigande bestäms av en normaliserad svenskhet. I sin analys verkar hon samtidigt vara ointresserad av att anklaga Oscar för att ha dålig attityd eller problematiska åsikter. I stället lyfter hon rasismen till en strukturell nivå: Oscars åsikt blir ett uttryck för dubbelheten i att formellt tillåta religionsfrihet och samtidigt försvåra firandet av religiösa högtider. Zara pekar på att religionsfriheten brister när barn förväntas anpassa sig till de fastslagna kulturuttryck som uppfattas som svenska.

Här pekar medforskaren Zara på hur rasism kan maskeras genom att rangordnande särskiljning sker på basis av föreställningar om religionstillhörighet och trosuttryck (Topolski 2018; Nilsson 2020). Hon sätter även fingret på hur rasistiska mikroaggressioner hänger samman med samhället i stort (Sue 2010), hur föreställningar om de andra som problemskapare leder till hanteringsstrategier som också kan inbegripa våld (Gardell 2015). Ett sådant uttryck för öppen eller direkt rasism (Elias 2015) är något som exemplifieras också av Fatima i fokusgrupp fem:

Där jag bodde förut [storstad i Sverige] var det många kristna. Det fanns några föräldrar som sa till sina barn att de inte skulle leka med oss för att vi är muslimer, jag och min syster och hela min familj. De sa "de är farliga, de dödar" och så. När vi gick och promenerade så brukade de kasta ägg på oss och säga "fy, muslimer" och sådana grejer.

Fatimas erfarenhet belyser hur antimuslimsk rasism, som återfinns på många håll i Sverige (Gardell 2018; Nilsson 2019; Brå 2021), även drabbar barn. På följdfrågan om någon vuxen hjälpte Fatima att hantera det hon utsatts för svarar hon nej utan att tveka. Hennes berättelse understryker därmed det som Zara påpekade ovan, nämligen att öppen rasism hänger samman med barns upplevelser av vardagsrasism. Den svenska skolans begränsning av barns kulturella trosuttryck kan ur barns perspektiv förstås som en institutionaliserad form av antimuslimsk rasism: Hassan i fokusgrupp fem säger att "mina föräldrar låter mig göra allt med vår religion [islam], men i skolan säger de nej. Min mamma fick prata med rektorn för att jag skulle få göra det.” 
Vardagsrasismens normalisering innebär att även barn använder sig av rasistiska tankefigurer. Ett exempel är bruket av kulinariska metaforer som medel för rasistisk särskiljning (Wyver 2019). Alexandra i fokusgrupp sex berättar att en klasskamrat "var lite mörkhyad och han blev kallad för 'choklad"'. Hon reagerade själv när hon stötte på denna mikroaggression, och säger därför i en efterföljande bisats: "Det tänker jag är lite rasistiskt." Även här används bestämningen "lite" som för att understryka att det inte handlar om öppen eller direkt rasism, utan snarare om en förtäckt form av vardagsrasism. Samma subtila mekanismer återkommer när rasistiska sorteringsprinciper präglar mellanstadiebarnens lek i gränslandet mellan fantasi och verklighet. I fokusgrupp tre berättar Ebba om en lek där "alla som var blonda och hade blåa ögon fick göra någonting, typ gå i tåg, jag minns inte, men något roligt, och så fick inte alla de andra, de med brunt hår och så, de fick inte vara med”. Ebba säger att leken skedde under en fritidsaktivitet, på barnens initiativ och utan vuxnas insyn. Den rangordnande särskiljningen mellan dem "som var blonda och hade blåa ögon" och "alla de andra" återspeglar inte bara de sorteringsmekanismer som genomsyrar svensk arbetsmarknad och svenska samhällsinstitutioner (Wolgast 2017; Lundström \& Wendt Höjer 2021), utan pekar också på den färgblindhet med vilken sådan rasism tonas ner och förminskas. Då vithetsnormen även präglar den svenska skolan (Dovemark 2013; Arneback \& Jämte 2017:110-112; Jonsson 2020), är det knappast förvånande att dess rasistiska sorteringsmekanismer även återspeglas i barnens lekar.

Samtidigt belyser Ebbas berättelse hur barn, även elever som själva är vita, kan identifiera vardagsrasism i leksituationer där vuxna saknar insyn eller inte förstår vad som pågår. Här påpekar emellertid barnen i fokusgruppstudien att de behöver vuxenvärldens stöd för att kunna agera antirasistiskt.

\section{"Jag vågade inte"}

En av mina följdfrågor, sedan barnen i de olika fokusgrupperna delgett sina erfarenheter av svensk vardagsrasism, var hur skolpersonal eller andra vuxna agerat. Ett återkommande svar var att vuxna helt enkelt inte sett problemet. Lilly (Fg8) berättar att "lärarna ser oftast inte sakerna som vi utsätts för" och Ebba (Fg3) menar att de "håller koll på om vi skadar oss, om någon gör illa sig, men inte vad vi gör". Alexandra (Fg6) säger att "det var ingen vuxen där, det var ju på rasten”. Barnen beskriver också skolpersonalens antirasistiska punktinsatser som otillräckliga: "varje gång som lärarna kom så slutade alla, men så fort läraren gick så fortsatte de” (Omari, Fg7). Vuxnas svaga insikt hänger på detta sätt ihop med bristande insyn, som när Ebba beskriver att de vuxna "stod och pratade" och därför inte såg barnens lekindelning mellan dem "som var blonda och hade blåa ögon" och "alla de andra" (Fg3).

Fokusgruppsdeltagarna förklarar även skolans oförmåga att se och motverka vardagsrasism med att vuxna inte litar på barns berättelser: "Ibland så behöver de bevis. När vi inte har bevis på det gör de typ ingenting åt det" (Fatima, Fg5). På detta sätt osynliggörs vardagsrasism genom att förminskas eller förnekas (Essed 1991; Dovemark 2013), eller genom att den som blivit utsatt själv misstänkliggörs eller betecknas som överkänslig (Ahmed 2021; Kristoffersson, Rönnqvist, Andersson m.fl. 2021). Den 
omvända bevisbördan gör även att barn som utsätts för öppen rasism väljer att inte söka stöd hos vuxenvärlden:

Alltså det har hänt, till exempel att någon kommer fram till mig och retar mig för min hudfärg. Då kanske jag vill säga till min lärare, eller om man vill säga till sin mamma, och sen tänker man liksom "äh, det här kommer säkert inte hända igen”. Och sen blir man påverkad och påverkad, och så sliter det liksom isär en, och ändå gör man ingenting för att man tänker bara "det här är säkert ingenting" (Toya, Fg4).

Toya finner det inte meningsfullt att söka stöd hos vuxna efter att ha blivit utsatt för rasistiska trakasserier. Hon tror inte att hennes lärare och föräldrar skulle inse allvaret och intalar sig i stället att händelsen inte kommer att upprepas. Men försöket att internalisera problemet misslyckas; Toya ser inte sin erfarenhet av rasism som ett uttryck för överkänslighet, trots att det är vad som förväntas av henne. Utan vuxenvärldens stöd skapar vithetsnormens förväntningar och hennes egen upplevelse en inre konflikt som "liksom sliter isär en". Situationen skulle sannolikt ha varit annorlunda om Toya tidigare sett vuxna agera mot rasism i skolan (Lund 2019; Arneback \& Jämte 2021).

I Rädda Barnens enkätstudie angav närmare hälften av de barn som sökt stöd vid utsatthet att de varit osäkra på om de verkligen fått hjälp (Abutaleb Rosenlundh, Lundström \& Vogel 2021). När jag visar detta resultat för medforskaren Noor (Fg1) nickar hon instämmande och sätter ord på uppgivenheten: "Man ska gå till typ en vuxen, men jag vet inte: vuxna - vad gör dom?" Frustrationen återspeglas även i andra fokusgrupper, där barnen understryker behovet av vuxenvärldens förståelse och stöd för att de ska kunna hantera rasism. När Ebba bevittnade leken som byggde på en rasistisk sorteringsprincip kände hon sig förhindrad att agera, hon berättar att "jag ville inte, eller jag vågade inte, säga typ 'alla kan ju vara med' för jag var rädd att alla skulle tycka jag var konstig". Här säger Ebba först hur hon inte "ville" ingripa, men korrigerar sedan påståendet till "jag vågade inte”. Hon förskjuter på så sätt ansvaret till de vuxna, som misslyckats med att skapa en trygg miljö där Ebba hade kunnat agera antirasistiskt.

Att vuxna uppmärksammar vardagsrasism är i sig ett viktigt instrument för trygghetsskapande (Arneback \& Jämte 2021). Medforskaren Zara påpekar att "när det är diskriminering eller rasism, då borde vuxna lägga sig i för att förhindra det" (Medforskarworkshop 3). Fatima i fokusgrupp fem säger att "när folk har kränkt mig, då brukar jag gå till vår lärare. Hon brukar ta in dem och så pratar vi om allt som har hänt, varför det har hänt." Andra fokusgruppsdeltagare menar att vuxna själva borde bli "bättre exempel och [behandla] folk mer lika" (Astrid, Fg3); de vill att lärarna "tar tag i det och pratar med hela klassen om det" (Alexandra, Fg6), att de ger "tips på vad barnen kan göra för att själva reda ut det" (Shadia, Fg1) eller att de utvecklar en mer träffsäker undervisning, eftersom "det är många som liksom inte riktigt vet om det de blivit utsatta för var rasism" (Olivia, Fg4). Det krävs med andra ord förhöjd uppmärksamhet för att den undflyende vardagsrasismen ska bli synlig. 


\section{"Det händer på riktigt"}

Vardagsrasisms subtila verkningar gör den svår att upptäcka för dem som passar in i vithetsnormen och som därför själva inte är utsatta. I stället för att uppmärksammas här och nu omförhandlas rasism till ett fenomen hemmahörande i en annan tid eller på en annan plats (Schmauch 2006:181-186). Låt oss återgå till fokusgrupp åtta:

Markus: Kan ni komma på någon särskild plats där rasism sker extra mycket? Mohamed: Som jag sa innan så är det i USA.

Markus: Om vi tänker i Sverige då, kan ni komma på någon plats eller situation? Mohamed: Jag har inte hört så mycket om rasism här i Sverige.

Isabella: I skolan kan det vara på raster och så. [...]

Ture: Det kan vara i protester. Det finns ju protester mot rasism, men det finns också, till exempel, sådana här tåg som man går där det är rasister och nazister som vill att det ska finnas kvar (Fg8).

$\mathrm{Nu}$ träder Mohamed in i samtalet. Han har suttit tyst när klasskamraterna irriterat beskrivit att de andra inte anpassar sig till "utgångspunkten i Sverige" genom att kräva ledighet vid "sina speciella högtider". Det är Mohamed som svarar på min fråga om var rasism förekommer, och han nämner då den amerikanska polisens våld mot svarta. Men den typen av öppen rasism har Mohamed "inte hört så mycket om" i Sverige." Här inflikar emellertid Isabella att rasism skulle kunna förekomma i skolan, "på raster och så", och öppnar därmed för möjligheten att se vardagsrasistiska mikroaggressioner också i barnens egen närmiljö. Ture förbiser Isabellas kommentar i sitt försök att identifiera rasism i Sverige. Han anger i stället demonstrationståg med "rasister och nazister" som ett avgränsat socialt fenomen där det förs fram extrema uppfattningar om att rasism borde "finnas kvar". Kopplingen till nazism reducerar på detta sätt rasism till en historisk anomali, ett mänsklighetens felsteg som i dag förkastas av det svenska samhället (Pred 2000). Men allt eftersom diskussionen fortgår närmar sig barnen i fokusgruppen Isabellas förslag om att rasism också skulle kunna förekomma i deras egen vardag. Oscar, som tidigare använde sin tongivande roll för att problematisera icke-kristna högtidsfiranden, för försiktigt in samtalet på Mohameds utsatthet:

Oscar: Rasism i gympasalen till exempel. Det här kanske inte är rasism, och i så fall är det en väldigt liten form av rasism, det är nog lite mer diskriminering, men det finns vissa som de pratar om och liksom säger deras namn på ett nedlåtande sätt. Till exempel på gympan.

Markus: Hur då, till exempel?

Oscar: Till exempel ... kan jag ta ditt namn Mohamed?

Mohamed: Ja, självklart.

Oscar: Då säger de typ så här [förlöjligar namnet].

Mohamed: Ja men det ...

Isabella: ... men det är typ lite så alla gör, som många barn gör. 
Oscar: Men, det fortsätter. Och nu menar jag inte att det här var Mohamed, utan ... ja.

Mohamed: Ja, för det här - det har hänt.

Oscar: Ja.

Mohamed: Det händer på riktigt. Det händer ofta, varje gång jag gör något som inte är rätt. Varje gång jag gör något fel, till exempel fotbollsplanen, direkt hör jag den [förlöjligande] rösten.

Här intar Mohamed, den enda av de åtta fokusgruppsdeltagarna som angett utländsk bakgrund, en ny position: han är själv utsatt för rasism. Samtalet tar därmed en vändning där deltagarna börjar upptäcka hur rasism pågår mitt ibland dem, på deras egen skola, i deras egen vardag. Vardagsrasismen blir synlig. Nu förändras barnens positioner och förhållningsätt. Mohamed verkar till en början tveksam till att definiera den pågående mobbningen som rasism, men när Oscar framhåller att "det fortsätter" tar Mohamed tillfället i akt och betonar att "det händer på riktigt". Efter att först ha förlagt rasismen till USA börjar Mohamed tala om sin egen utsatthet. Han återger sitt perspektiv på vardagsrasism för sina lyssnande klasskamrater.

$\mathrm{Nu}$ börjar Mohamed själv ställa frågor, vilket ytterligare förstärker hans position i gruppsamtalet (León Rosales 2020). I början av fokusgruppsintervjun var Oscar tongivande; när han delgav sin åsikt om trosuttryck, och jag frågade om de andra höll med, övertog han mitt frågande och vände sig retoriskt direkt till de andra barnen: "Är det någon som inte tycker så?" Han talade då utifrån en vithetsnorm enligt vilken de andra uppfattas som ett problem. Senare under samtalet förändras dessa positioneringar, allt eftersom Mohamed börjar ta makt över den situation i vilken han först utpekats som offer. Under denna process utmanas också vithetsnormen. Det är nu Mohameds erfarenhet som de andra fokusgruppsdeltagarna behöver förhålla sig till. Efter att barnen hört och även bekräftat Mohamed tar han ytterligare ett steg för att klargöra sitt perspektiv på vardagsrasism. Mohamed tittar direkt mot datorns webbkamera och vänder sig till synes till mig, till vuxenvärlden:

Det är så att rasism också kan göra dig irriterad, att de snackar om din bakgrund och sånt. Jag tycker när man snackar om föräldrar och rasism ... all mobbning, det är bara för långt. För vad skulle $d u$ göra om du var i den situationen? Vad skulle $d u$ göra om du satt där och blev mobbad?

\section{Barns perspektiv på svensk vardagsrasism}

Varför fortsätter skolelever att utsättas för rasism trots den svenska skolans antirasistiska ambitioner? Den här artikeln besvarar frågan genom att fokusera på vardagsrasism (Essed 1991), subtila uttryck för rangordnande särskiljning utifrån stereotypa föreställningar om ras, etnicitet, kultur, nationalitet eller religion. Ett sådant analysfokus bidrar till förståelsen av rasismens fortlevnad i miljöer där den aktivt fördöms (Schömer 2016; Mulinari \& Neergaard 2017). Den svenska skolan är en sådan samhällsinstitu- 
tion; skolan arbetar för att motverka rasism (SFS 2010:800; Skolverket 2019), men likväl rapporterar barn om fortsatt utsatthet (Abutaleb Rosenlundh, Lundström \& Vogel 2021; Barnombudsmannen 2021; Loodberg \& Abera 2021). Med hjälp av barns perspektiv får vi en djupare inblick i hur vardagsrasism verkar i den skolmiljö där rasism officiellt motverkas.

Genom analys av åtta fokusgruppsintervjuer med mellanstadieelever, genomförda med hjälp av tre medforskande barn i samma ålder, framträder en bild av skolvardagen där rasistiska mikroaggressioner avsiktligt eller oavsiktligt bidrar till rangordnande särskiljning (Sue 2010). Vardagsrasismen i skolan osynliggörs samtidigt av den vithetsnorm som upprätthåller särskiljning mellan grupper utifrån hudfärg (Lundström \& Hübinette 2020:20-23); skolans antirasistiska arbete begränsas av den färgblindhet som förbiser vithetsnormen och förminskar rasismens historiska kontinuitet som samhällsstruktur (Lentin 2011; Goldberg 2015; Pinder 2015). Samtidigt visar analysen av fokusgruppsintervjuerna att barn själva är i stånd att avslöja vardagsrasism i skolan. Men här efterfrågar de vuxnas stöd för att våga agera antirasistiskt. Skolpersonalen behöver hantera enskilda elevers rasistiska beteende (Miklikowska, Thijs \& Hjerm 2019; Mattsson \& Johansson 2020), men det krävs också djupare insikt för att kunna upptäcka och motverka vardagsrasism i skolan (León Rosales 2014; Arneback \& Jämte 2017; Lynch, Swartz \& Isaacs 2017). Inte minst behöver vuxna som upprätthåller vithetsnormen förstå hur vardagsrasism verkar omkring och genom dem (Schwarz \& Lindqvist 2018; Åberg \& Olin-Scheller 2018; Lund 2019). Barns perspektiv kan bidra till en sådan lärandeprocess genom att klargöra hur rasism på olika sätt präglar vardagen inom den svenska skolan.

\section{Referenser}

Abutaleb Rosenlundh, S., M. Lundström \& A. Vogel (2021) Vuxna - vad gör dom? Barns röster om rasism i skolan. Stockholm: Rädda Barnen.

Ahmadi, F., M. Darvishpour, N. Ahmadi \& I. Palm (2020) "Diversity barometer. Attitude changes in Sweden", Nordic social work research 10(1):21-38. https://doi.or g/10.1080/2156857x.2018.1527242

Ahmed, S. (2021) Complaint! Durham: Duke University Press. https://doi. org/10.1515/9781478022336

Alanen, L. (2001) "Explorations in generational analysis", 11-22 i L. Alanen \& B. Mayall (red.) Conceptualising child-adult relations. London: Routledge. https://doi. org/10.4324/9780203467220

Alderson, P. (2008) "Children as researchers. Participation rights and research methods", 276-290 i P. Christensen \& A. James (red.) Research with children. Perspectives and practices. London: Routledge. https://doi.org/10.4324/9780203964576-21

Alderson, P. \& V. Morrow (2004) Ethics, social research and consulting with children and young people. Ilford: Barnardo's.

Arneback, E. \& J. Jämte (2017) Att motverka rasism i förskolan och skolan. Stockholm: Natur \& Kultur. 
Arneback, E. \& J. Jämte (2021) "How to counteract racism in education. A typology of teachers' anti-racist actions", Race ethnicity and education. Nätpublicering. https:// doi.org/10.1080/13613324.2021.1890566

Aronsson, K. (2012) "Barnperspektiv. Att avläsa barns utsatthet", Locus 24(1-2):95-111.

Asplund, A., S. Thalberg \& C. Tovatt (2018) Barn och migration. Stockholm: Delegationen för migrationsstudier.

Barnombudsmannen (2018) Utanförskap, våld och kärlek till orten. Barns röster om att växa upp i utsatta kommuner och förorter. Stockholm: Barnombudsmannen.

Barnombudsmannen (2021) Om barns och ungas utsatthet för rasism. Stockholm: Barnombudsmannen.

Bayram Özdemir, S. \& M. Özdemir (2020) "The role of perceived inter-ethnic classroom climate in adolescents' engagement in ethnic victimization. For whom does it work?", Journal of youth and adolescence 49(6):1328-1340. https://doi.org/10.1007/ s10964-020-01228-8

Behtoui, A., F. Hertzberg, R. Jonsson, R. León Rosales \& A. Neergaard (2019) "Sweden. The otherization of the descendants of immigrants", 999-1034 i P. Stevens \& G. Dworkin (red.) The Palgrave handbook of race and ethnic inequalities in education. London: Palgrave Macmillan. https://doi.org/10.1007/978-3-319-94724-2_23

Behtoui, A. \& S. Jonsson (2013) "Rasism - särskiljandets och rangordningens politik", 168-198 i M. Dahlstedt \& A. Neergaard (red.) Migrationens och etnicitetens epok. Kritiska perspektiv i etnicitets- och migrationsstudier. Malmö: Liber.

Bergnehr, D. (2018) "Children's influence on wellbeing and acculturative stress in refugee families", International journal of qualitative studies on health and well-being 13 (supplement 1):1-9. https://doi.org/10.1080/17482631.2018.1564517

Bergnehr, D. (2019) "Barnperspektiv, barns perspektiv och barns aktörskap. En begreppsdiskussion", Nordisk tidsskrift for pedagogikk og kritikk 5:49-61. https://doi. org/10.23865/ntpk.v5.1373

Bjereld, Y., K. Daneback \& M. Petzold (2015) ”Differences in prevalence of bullying victimization between native and immigrant children in the Nordic countries. A parent-reported serial cross-sectional study", Child: Care, health, and development 41(4):593-599. https://doi.org/10.1111/cch.12184

Bonilla-Silva, E. (2017) Racism without racists. Color-blind racism and the persistence of racial inequality in the United States. Lanham: Rowman \& Littlefield.

Bryant, A. \& K. Charmaz (2012) "Grounded theory and psychological research", 39-56 i H. Cooper, P. Camic, D. Long, A. Panter, D. Rindskopf \& K. Sher (red.) APA handbook of research methods in psychology. Volume 2. Washington: American Psychological Association.

Brå (2021) Islamofobiska hatbrott. Stockholm: Brottsförebyggande rådet.

Christensen, P. \& A. James (2017) "Introduction. Researching children and childhood cultures of communication", 1-10 i P. Christensen \& A. James (red.) Research with children. Perspectives and practices. London: Routledge. https://doi. org/10.4324/9780203964576-7

Christensen, P. \& A. Prout (2002) "Working with ethical symmetry in social research 
with children", Childhood 9(4):477-497. https://doi.org/10.1177/0907568202009 004007

Clark, A., A.T. Kjørholt \& P. Moss (2005) "Introduction", 1-16 i A. Clark, A. Kjørholt $\&$ P. Moss (red.) Beyond listening. Children's perspectives on early childhood services. Bristol: Policy Press.

Dahlstedt, M. (2017) "Young people in suburbs feel discriminated, but hopeful", Sociologisk forskning 54(4):341-346.

Dahlstedt, M. (red.) (2018) Förortsdrömmar. Ungdomar, utanförskap och viljan till inkludering. Linköping: Linköping University Press.

De los Reyes, P. \& M. Wingborg (2002) Vardagsdiskriminering och rasism i Sverige. En kunskapsöversikt. Norrköping: Integrationsverket.

Dovemark, M. (2013) "How private 'everyday racism' and public 'racism denial' contribute to unequal and discriminatory educational experiences", Ethnography and education 8(1):16-30. https://doi.org/10.1080/17457823.2012.717199

Edling, S. (2018) Att vilja andra väl är inte alltid smärtfritt. Att motverka kränkningar och diskriminering i förskola och skola. Lund: Studentlitteratur.

Elias, S. (2015) "Racism, overt", i J. Stone, R. Dennis, P. Rizova, A. Smith \& X. Hou (red.) The Wiley Blackwell encyclopedia of race, ethnicity, and nationalism. Hoboken: Wiley Blackwell. https://doi.org/10.1002/9781118663202.wberen398

Essed, P. (1991) Understanding everyday racism. An interdisciplinary theory. London: Sage.

Furborg, A. \& O. Cox (2016) Friends nätrapport 2016. Stockholm: Friends.

Gardell, M. (2015) Raskrigaren. Seriemördaren Peter Mangs. Stockholm: Leopard förlag.

Gardell, M. (2018) Moskéers och muslimska församlingars utsatthet och säkerhet i Sverige 2018. Uppsala: Uppsala universitet.

Goldberg, D.T. (2015) Are we all postracial yet? Cambridge: Polity.

Hagström, M. (2018) Raka spår, sidospår, stopp. Vägen genom gymnasieskolans språkintroduktion som ung och ny $i$ Sverige. Linköping: Linköpings universitet.

Halldén, G. (2003) "Barnperspektiv som ideologiskt eller metodologiskt begrepp", Pedagogisk forskning i Sverige 8(1-2):12-23.

Halldén, G. (2009) "Barnperspektiv. Ett ideologiskt laddat begrepp och oprecist som analytiskt verktyg", Locus 409(3-4):4-20.

Hernwall, P. (2013) "Barn som medforskare. Ökat medvetande genom deltagande", 215-233 i K. Helander (red.), Nu vill jag prata! Barns röster i barnkulturen. Stockholm: Centrum för barnkulturforskning.

Herz, M. \& P. Lalander (2017) "Being alone or becoming lonely? The complexity of portraying 'unaccompanied children' as being alone in Sweden", Journal of youth studies 20(8):1062-1076. https://doi.org/10.1080/13676261.2017.1306037

Hillén, S. (2013) Barn som medforskare. En metod med potential för delaktighet. Göteborg: Göteborgs universitet.

Hjerm, M., I. Johansson Sevä \& L. Werner (2018) "How critical thinking, multicultural education and teacher qualification affect anti-immigrant attitudes", International studies in sociology of education 27(1):42-59. https://doi.org/10.1080/09620214.201 8.1425895 
Johansson, B. (2013) "Att involvera barn i forskning", 202-214 i K. Helander (red.), Nu vill jag prata! Barns röster i barnkulturen. Stockholm: Centrum för barnkulturforskning.

Johansson, E. (2003) "Att närma sig barns perspektiv. Forskares och pedagogers möten med barns perspektiv", Pedagogisk forskning i Sverige 8(1-2):42-57.

Jonsson, R. (2015) Värst i klassen. Berättelser om stökiga pojkar i innerstad och förort. Stockholm: Ordfront.

Jonsson, R. (2018) "Swedes can't swear. Making fun at a multiethnic secondary school", Journal of language, identity \& education 17(5):320-335. https://doi.org/10 $.1080 / 15348458.2018 .1469412$

Jonsson, R. (2020) "Antirasismens andra. Berättelser om förortselever i innerstadens gymnasium", Educare 4:69-97. https://doi.org/10.24834/educare.2109.4.5

Kadarik, K. (2019) Moving out, moving up, becoming employed. Studies in the residential segregation and social integration of immigrants in Sweden. Uppsala: Uppsala universitet.

Karlsson, S. (2019) "'They cry, cry, they want to go to school.' The micro-politics of asylum-seeking children's articulated emotions and belonging in relation to the Swedish school”, Children \& society 33(5):429-442. https://doi.org/10.1111/chso.12317

Katzin, M. (2021) Skolgairdsrasism, konspirationsteorier och utanförskap. En rapport om antisemitism och det judiska minoritetskapet i Malmös förskolor, skolor, gymnasier och vuxenutbildning. Malmö: Malmö stad.

Khayati, K. (2017) "Stigmatisering och rasism i det svenska migrationssamtalet och det diasporiska motståndet", Sociologisk forskning 54(1-2):11-30.

Kristoffersson, E., H. Rönnqvist, J. Andersson, C. Bengs \& K. Hamberg (2021) "'It was as if I wasn't there'. Experiences of everyday racism in a Swedish medical school", Social science \& medicine 270:1-9. https://doi.org/10.1016/j.socscimed.2021.113678

Kuckartz, U. \& S. Rädiker (2019) Analyzing qualitative data with MAXQDA. Cham: Springer. https://doi.org/10.1007/978-3-030-15671-8

Lentin, A. (2011) "What happens to anti-racism when we are post race?", Feminist legal studies 19(2):159. https://doi.org/doi:10.1007/s10691-011-9174-5

Leon Rosales, R. (2016) "Rasismerna”, 78-105 i A. Marega \& S. Gusic (red.) Det andra uppdraget. Till försvar för skolans likabehandlingsarbete. Lund: Universus Academic Press.

León Rosales, R. (2014) '”Där är alla svenskar, inte en enda är svartskalle'. Svenskhetsnorm i en multietnisk skola”, 151-188 i L. Martinsson \& R. Eva (red.) Skola $i$ normer. Malmö: Gleerups Utbildning AB.

León Rosales, R. (2020) "Att säga som det är - (in)tolerans som maskulin performans", Educare 4:94-119. https://doi.org/10.24834/educare.2019.4.2

Lindmark, D. \& O. Sundström (2016) De historiska relationerna mellan svenska kyrkan och samerna. En vetenskaplig antologi. Skellefteå: Artos \& Norma bokförlag.

Ljung Egeland, B. (2015) Berättelser om tillhörighet. Om barn med migrationsbakgrund på en mindre ort. Karlstad: Karlstads universitet.

Loodberg, M. \& N. Abera (2021) Friendsrapporten 2021. Stockholm: Friends. 
Loodberg, M. \& F. Warg (2019) Friendsrapporten 2019. Stockholm: Friends.

Lund, A. (2019) "Preparedness as a counter-memory. School desegregation, social chances and life chances", Ethnic and racial studies 42(13):2318-2325. https://doi. org/10.1080/01419870.2019.1605091

Lundström, C. \& T. Hübinette (2020) Vit melankoli. En analys av en nation i kris. Göteborg: Makadam.

Lundström, M. \& T. Lundström (2016) "Hundra år av radikal nationalism”, Arkiv. Tidskrift för sambällsanalys 5:39-66. https://doi.org/10.13068/2000-6217.5.2

Lundström, M. \& F. Wendt Höjer (2021) Erfarenheter av rasism i kontakt med svenska myndigheter och andra offentliga verksamheter. En kunskapsöversikt. Stockholm: Forum för levande historia.

Lynch, I., S. Swartz \& D. Isaacs (2017) "Anti-racist moral education. A review of approaches, impact and theoretical underpinnings from 2000 to 2015 ", Journal of moral education 46(2):129-144. https://doi.org/10.1080/03057240.2016.1273825

Lööw, H. (2017) "I gränslandet. Symbiosen mellan det organiserade och oorganiserade”, 21-87 i M. Gardell, H. Lööw \& M. Dahlberg-Grundberg (red.) Den ensamme terroristen? Om lone wolves, näthat och brinnande flyktingförläggningar. Stockholm: Ordfront.

Mattsson, C. \& T. Johansson (2019) Life trajectories into and out of contemporary neonazism. Becoming and unbecoming the hateful other. Abingdon: Routledge. https:// doi.org/10.4324/9780429284762

Mattsson, C. \& T. Johansson (2020) "The hateful other. Neo-nazis in school and teachers' strategies for handling racism", British journal of sociology of education 41(8):1149-1163. https://doi.org/10.1080/01425692.2020.1823204

Mattsson, K. (2005) "Diskrimineringens andra ansikte. Svenskhet och 'det vita västerländska", 139-158 i Utredningen om makt, integration och strukturell diskriminering, Bortom vi och dom. Teoretiska reflektioner om makt, integration och strukturell diskriminering. SOU 2005:41. Stockholm: Fritzes offentliga publikationer.

Mayall, B. (2000) "The sociology of childhood in relation to children's rights", The international journal of children's rights 8(3):243-259. https://doi. org/10.1163/15718180020494640

Miklikowska, M., A. Bohman \& P. Titzmann (2019) "Driven by context? The interrelated effects of parents, peers, classrooms on development of prejudice among Swedish majority adolescents", Developmental psychology 55(11):2451-2463. https:// doi.org/10.1037/dev0000809

Miklikowska, M., J. Thijs \& M. Hjerm (2019) "The impact of perceived teacher support on anti-immigrant attitudes from early to late adolescence", Journal of youth and adolescence 48(6):1175-1189. https://doi.org/10.1007/s10964-019-00990-8

Moosa-Mitha, M. (2005) "A difference-centred alternative to the theorization of children's citizenship rights", Citizenship studies 9(4):369-388. https://doi. org/10.1080/13621020500211354

Motsieloa, V. (2003) "Det måste vara någonting annat." En studie om barns upplevelser av rasism i vardagen. Stockholm: Rädda Barnen. 
Mulinari, D. \& A. Neergaard (2017) "Theorising racism. Exploring the Swedish racial regime", Nordic journal of migration research 7(2):88-96. https://doi.org/10.1515/ njmr-2017-0016

Nilsson Folke, J. (2017) Lived transitions. Experiences of learning and inclusion among newly arrived students. Stockholm: Stockholms universitet.

Nilsson, P.-E. (2019) "Burka songs 2.0. The discourse on Islamic terrorism and the politics of extremization in Sweden", Journal of religion and violence. https://doi. org/10.5840/jrv201942264

Nilsson, P.-E. (2020) "The crocodile and the gardener. Swedish radical nationalism and critique of religion", 124-134 i M. Lövheim \& M. Stenmark (red.) A constructive critique of religion. Encounters between Christianity, Islam, and non-religion in secular societies. London: Bloomsbury. https://doi.org/10.5040/9781350113121

Nygren, J., S. Lindberg, P. Wärnestål \& P. Svedberg (2017) "Involving children with cancer in health promotive research. A case study describing why, what, and how", JMIR research protocols 6(2):1-13. https://doi.org/10.2196/resprot.7094

Odenbring, Y. \& T. Johansson (2019) "'If they're allowed to wear a veil, we should be allowed to wear caps.' Cultural diversity and everyday racism in a rural school in Sweden”, Journal of rural studies 72:85-91. https://doi.org/10.1016/j.jrurstud.2019.10.033

Pérez-Aronsson, F. (2019) "’Åh vad kul, nu börjar det invandrare på skolan!' Ungas upplevelser av rasism och överlevnadsstrategier i svenska skolan”, Educare 4:76-100. https://doi.org/10.24834/educare.2019.4.4

Pérez Aronsson, F. (2020) Do I look white? Creating community in online safe spaces for racialized youth. Stockholm: Stockholms universitet.

Pinder, S.O. (2015) Colorblindness, post-raciality, and whiteness in the United States. Cham: Springer. https://doi.org/10.1057/9781137431103

Polismyndigheten (2021) Lägesbild över utsatta områden. Regeringsuppdrag 2021. Stockholm: Polismyndigheten.

Pred, A. (2000) Even in Sweden. Racisms, racialized spaces, and the popular geographical imagination. Berkeley: University of California Press.

Schmauch, U. (2006) Den osynliga vardagsrasismens realitet. Umeå: Umeå universitet.

Schwarz, E. \& B. Lindqvist (2018) "Exploring the phenomenology of whiteness in a Swedish preschool class", International journal of early childhood 50(1):1-14. https:// doi.org/10.1007/s13158-018-0210-3

Schömer, E. (2016) "Sweden, a society of covert racism. Equal from the outside Everyday racism and ethnic discrimination in Swedish society", Oñati socio-legal series 6(3):837-845.

SFS 2008:567. Diskrimineringslag. Kapitel 1, S 4-5. Stockholm: Arbetsmarknadsdepartementet.

SFS 2010:800. Skollag. Kapitel 6, \$10. Stockholm: Utbildningsdepartementet.

Sixtensson, J. (2018) Härifrän till framtiden. Om gränslinjer, aktörskap och motstånd $i$ tjejers vardagsliv. Malmö: Malmö universitet. https://doi. org/10.24834/2043/23682 
Skolverket (2019) Läroplan för grundskolan, förskoleklassen och fritidshemmet 2011. Stockholm: Norstedts Juridik.

Solberg, A. (1996) "The challenge in child research. From 'being' to 'doing'", 53-65 i J. Brannen \& M. O'Brien (red.) Children in families. Research and policy. London: Routledge. https://doi.org/10.4324/9780203453803

Sommer, D., I. Pramling Samuelsson \& K. Hundeide (2011) Barnperspektiv och barnens perspektiv $i$ teori och praktik. Stockholm: Liber.

Spyrou, S. (2011) "The limits of children's voices. From authenticity to critical, reflexive representation", Childhood 18(2):151-165. https://doi.org/10.1177/0907568210387834

Statens medieråd (2019) Ungar och medier 2019. Stockholm: Statens medieråd.

Statens medieråd (2020) Unga, medier och psykisk ohälsa. En rapport om svenska ungdomars självskattade psykiska välbefinnande i relation till deras självskattade medieanvändning. Stockholm: Statens medieråd.

Sue, D.W. (2010) Microaggressions in everyday life. Race, gender, and sexual orientation. Hoboken: Wiley.

Sylwander, K. (2020) Whores, hijabs, and heart emojis. Affective explorations of aggression against girls online. Stockholm: Stockholm universitet.

Tisdall, K., J. Davis \& M. Gallagher (2009) Researching with children and young people. Research design, methods, and analysis. Los Angeles: Sage. https://doi. org/10.4135/9781446268315

Topolski (2018) "The race-religion constellation. A European contribution to the critical philosophy of race", Critical philosophy of race 6(1):58-81. https://doi. org/10.5325/critphilrace.6.1.0058

Utredningen om makt, integration och strukturell diskriminering (2005) Bortom vi och dom. Teoretiska reflektioner om makt, integration och strukturell diskriminering. SOU 2005:41. Stockholm: Fritzes offentliga publikationer.

Utredningen om strukturell diskriminering på grund av etnisk eller religiös tillhörighet (2005) Det blågula glashuset. Strukturell diskriminering i Sverige. SOU 2005:56. Stockholm: Fritzes offentliga publikationer.

Wacquant, L., T. Slater \& V.B. Pereira (2014) "Territorial stigmatization in action", Environment and planning A. Economy and space 46(6):1270-1280. https:/doi. org/10.1068/a4606ge

Wall, J. (2012) "Can democracy represent children? Toward a politics of difference", Childhood 19(1):86-100. https://doi.org/10.1177/0907568211406756

Wernesjö, U. (2020) "Across the threshold. Negotiations of deservingness among unaccompanied young refugees in Sweden", Journal of ethnic and migration studies 46(2):389-404. https://doi.org/10.1080/1369183x.2019.1584701

Wolgast, S. (2017) How does the job applicants' ethnicity affect the selection process? Norms, preferred competencies and expected fit. Lund: Lunds universitet.

Woodhead, M. \& D. Faulkner (2008) "Subjects, objects or participants? Dilemmas of psychological research with children", 10-39 i P. Christensen \& A. James (red.) Research with children. Perspectives and practices. London: Routledge. https://doi. org/10.4324/9780203964576-8 
Wyver, R. (2019) "Eating the [m] other. Exploring Swedish adoption consumption fantasies", Genealogy 3(3):47. https://doi.org/10.3390/genealogy3030047

Åberg, M. \& C. Olin-Scheller (2018) "Wolf cries. On power, emotions and critical literacy in first-language teaching in Sweden", Gender and education 30(7):882-898. https://doi.org/10.1080/09540253.2017.1376041

\section{Författarpresentation}

Markus Lundström forskar om sociala villkor och politisk idéproduktion med särskilt fokus på sociala rörelser. Han är knuten till Sociologiska institutionen och Centrum för mångvetenskaplig forskning om rasism vid Uppsala universitet.

\section{Kontaktuppgifter}

Markus Lundström

Centrum för mångvetenskaplig forskning om rasism, Uppsala universitet Thunbergsvägen 3C, 75120 Uppsala markus.lundstrom@cemfor.uu.se 